Article

\title{
The Effect of Yeast and Roughage Concentrate Ratio on Ruminal pH and Protozoal Population in Thai Native Beef Cattle
}

\author{
Kampanat Phesatcha ${ }^{1, * \mathbb{D}}$, Burarat Phesatcha ${ }^{2} \mathbb{D}$, Metha Wanapat ${ }^{3}\left(\mathbb{D}\right.$ and Anusorn Cherdthong $^{3, *(D)}$ \\ 1 Department of Animal Science, Faculty of Agriculture and Technology, Nakhon Phanom University, \\ Nakhon Phanom 48000, Thailand \\ 2 Department of Agricultural Technology and Environment, Faculty of Sciences and Liberal Arts, \\ Rajamangala University of Technology Isan, Nakhon Ratchasima 30000, Thailand; \\ Burarat_kat@hotmail.co.th \\ 3 Tropical Feed Resources Research and Development Center (TROFREC), Department of Animal Science, \\ Faculty of Agriculture, Khon Kaen University, Khon Kaen 40002, Thailand; metha@kku.ac.th \\ * Correspondence: kampanatmon@gmail.com (K.P.); anusornc@kku.ac.th (A.C.); Tel.: +66-4320-2362 (A.C.)
}

Citation: Phesatcha, K.; Phesatcha, B. Wanapat, M.; Cherdthong, A. The Effect of Yeast and Roughage Concentrate Ratio on Ruminal pH and Protozoal Population in Thai Native Beef Cattle. Animals 2022, 12, 53. https://doi.org/10.3390/ ani12010053

Academic Editor: Brian J. Leury

Received: 7 November 2021

Accepted: 7 December 2021

Published: 28 December 2021

Publisher's Note: MDPI stays neutral with regard to jurisdictional claims in published maps and institutional affiliations.

Copyright: (C) 2021 by the authors. Licensee MDPI, Basel, Switzerland. This article is an open access article distributed under the terms and conditions of the Creative Commons Attribution (CC BY) license (https:// creativecommons.org/licenses/by/ $4.0 /)$.
Simple Summary: As a result of the recent ban on antibiotics in feed, animal probiotics are becoming increasingly popular. Yeast is extensively used as both a probiotic and prebiotic in the gastrointestinal tracts of ruminants. The purpose of this study is to determine how adding yeast (Saccharomyces cerevisiae) to the diet and changing the roughage-to-concentrate ratio ( $\mathrm{R}: \mathrm{C}$ ratio) affects nutrient consumption, rumen fermentation, microbial protein synthesis, and protozoal population in Thai native beef cattle. The roughage source was urea-calcium-hydroxide-treated rice straw. The findings suggest that supplementing with a R:C ratio of 40:60 and a LY of $4 \mathrm{~g} / \mathrm{hd} / \mathrm{d}$ boosted nutrient digestibility, volatile fatty acid (VFA) production, propionic acid $\left(\mathrm{C}_{3}\right)$ in particular, and microbial protein synthesis while lowering protozoal population.

Abstract: The objective of this research is to investigate the effect of yeast (Saccharomyces cerevisiae) adding and roughage-to-concentrate ratio ( $\mathrm{R}: \mathrm{C}$ ratio) on nutrients utilization, rumen fermentation efficiency, microbial protein synthesis, and protozoal population in Thai native beef cattle. Four Thai native beef cattle, weighing an average of $120 \pm 10 \mathrm{~kg}$ live weight, were randomly assigned to four dietary treatments using a $2 \times 2$ factorial arrangement in a $4 \times 4$ Latin square design. Factor A was the level of roughage-to-concentrate ratio (R:C ratio) at 60:40 and 40:60; factor B was the levels of live yeast (LY) supplementation at 0 and $4 \mathrm{~g} / \mathrm{hd} / \mathrm{d}$; urea-calcium-hydroxide-treated rice straw were used as a roughage source. Findings revealed that total intake and digestibility of dry matter (DM), organic matter $(\mathrm{OM})$, and crude protein $(\mathrm{CP})$ were increased $(p<0.05)$ by both factors, being greater for steers fed a R:C ratio of 40:60 supplemented with $4 \mathrm{~g} \mathrm{LY} / \mathrm{hd} / \mathrm{d}$. Ruminal ammonia nitrogen, total volatile fatty acid (VFA), and propionate $\left(C_{3}\right)$ were increased $(p<0.05)$ at the R:C ratio of 40:60 with LY supplementation at $4 \mathrm{~g} / \mathrm{hd} / \mathrm{d}$, whereas rumen acetate $\left(C_{2}\right)$ and the $C_{2}$ to $C_{3}$ ratio were decreased $(p<0.05)$. With a high level of concentrate, LY addition increased total bacterial direct counts and fungal zoospores $(p<0.05)$, but decreased protozoal populations $(p<0.05)$. High-concentrate diet and LY supplementation increased nitrogen absorption and the efficiency of microbial nitrogen protein production. In conclusion, feeding beef cattle with $4 \mathrm{~g} / \mathrm{hd} / \mathrm{d}$ LY at a R:C ratio of 40:60 increased $\mathrm{C}_{3}$ and nutritional digestibility while lowering protozoal population.

Keywords: beef cattle; yeast addition; rumen fermentation; feed digestibility

\section{Introduction}

One of the approaches used to enhance growth performance of beef cattle is the use of a high-energy diet. High-energy diets are defined by a high carbohydrate content, which 
can lead to rapid ruminal production of short-chain fatty acids (SCFAs), which are the ruminant host's principal energy source [1]. The fast accumulation of SCFAs in the rumen reduces buffering capacity and may result in subacute ruminal acidosis (SARA) [2,3].

It has been reported the LY can reduce rumen $\mathrm{pH}$ fluctuation, in part through decreasing lactate accumulation in the rumen fluid due to activation of microbes which change lactate into SCFAs [4]. When LY is added to a meal that is high in rapidly fermentable carbohydrates, the lactate content drops and the rumen $\mathrm{pH}$ rises. It may be higher in starch-rich meals because starch-rich diets result in a larger acid load, requiring more physically effective fiber to maintain a normal rumen environment [5]. The more stable rumen environment caused by introducing LY to starch-rich diets may result in less demand for physically effective fiber, justifying improvements in dry matter intake that improve milk and milk component production [6]. Rumen acidosis can occur as a result of carbohydrate formulation errors in diets that are already high in starch [7]. LY was primarily used in young ruminants to promote gut health and to promote the formation of the intestinal bacteria involved in feed digestion. Further developments resulted in more sophisticated LY combinations aimed at increasing fiber digestion and reducing ruminal acidosis in mature cattle [8].

LY has been found to help ruminants digest feed as well as increasing digestibility of nutrients, enhancing VFA proportions, minimizing $\mathrm{pH}$ decreased, lowering ruminal ammonia nitrogen, and improving microbiome $[9,10]$. So far, LY has been shown to give rumen microbes numerous growth factors, provitamins, and other stimulants. LY lowers the rumen's redox potential and encourages the proliferation of bacteria-mostly cellulose consumers-which increases the rate of fiber decomposition [11]. Additionally, S. cerevisiae can scavenge the available oxygen to maintain metabolic activity, lowering the rumen's redox potential [12].

Broadway et al. [13] found that yeast supplementation had a variety of impacts in the rumen, including higher ruminal $\mathrm{pH}$ and VFA concentrations, decreased methane $\left(\mathrm{CH}_{4}\right)$ generation, and increased overall numbers of microorganisms and cellulolytic bacteria. A reduction of enteric $\mathrm{CH}_{4}$ production has been noted in cattle supplemented with $4 \mathrm{~g}$ of S. cerevisiae. Thus, LY can be another feed strategy for improving environmental circumstances [14]. As a result, the goals of this study were to investigate the impact of the R:C ratio with LY addition on total feed intake, feed digestibility, rumen characteristics and microbial population in Thai native beef cattle.

\section{Materials and Methods}

\subsection{Ethical Procedure}

Animal involved in this study were approved by the Animal Ethics Committee of Nakhon Phanom University (AENPU A2/2560), based on the Ethics of Animal Experimentation of National Research Council of Thailand.

\subsection{Dietary Treatments and Experimental Design}

Four Thai native beef cattle, weighing an average of $120 \pm 10 \mathrm{~kg}$ live weight, were randomly assigned to four dietary treatments using a $2 \times 2$ factorial arrangement in a $4 \times 4$ Latin square design. Factor $\mathrm{A}$ was the level of roughage-to-concentrate ratio (R:C ratio) at 60:40 and 40:60; factor $B$ was the levels of live yeast (LY) supplementation at 0 and $4 \mathrm{~g} / \mathrm{hd} / \mathrm{d}\left(6.0 \times 10^{6}\right.$ colony-forming units); urea-calcium-hydroxide-treated rice straw (Oryza sativa L.) was used as a roughage source. Table 1 shows the diet compositions and ingredients of concentrate mixtures, and urea-calcium-hydroxide-treated rice straw. Before the treatments were imposed, the animals were injected with $10 \mathrm{~mL}$ of vitamins $\mathrm{A}, \mathrm{D}_{3}$, and $\mathrm{E}$ and were drenched with anthelmintics prior to the experiment. Two kilograms of urea and of calcium hydroxide $\left(\mathrm{Ca}(\mathrm{OH})_{2}\right)$ were added to 100 litters of rice straw to make the rice-straw-treated urea and $\left(\mathrm{Ca}(\mathrm{OH})_{2}\right)$ [15]. The brewer's yeast strain $S$. cerevisiae $\left(6 \times 10^{6} \mathrm{cfu} / \mathrm{g}\right.$, Renu Nakhon, Nakhon Phanom, Thailand) was collected from the Renu Nakhon district, Nakhon Phanom Province, Thailand. 
Table 1. Ingredient composition of concentrate and chemical composition of concentrate and treated rice straw offered to steers.

\begin{tabular}{ccc}
\hline Items & Concentrate & $\begin{array}{c}\text { Urea and Calcium } \\
\text { Hydroxide Treated Rice } \\
\text { Straw }\end{array}$ \\
\hline Ingredients, \% as fresh basis & 75.0 & \\
Cassava chip & 15.0 & \\
Coconut meal & 4.0 & \\
Rice bran & 2.5 & \\
Urea & 2.0 & \\
Molasses & 0.5 & \\
Mineral mixture & 0.5 & \\
Salt & 0.5 & \\
Sulfur & 100.0 & \\
Total & & \\
Chemical composition & 92.7 & 11.3 \\
Dry matter, \% & & 5.6 \\
\% of dry matter & 92.6 & 72.8 \\
Organic matter & 7.4 & 45.9 \\
Ash & 14.1 & \\
Crude protein & 27.2 & \\
Neutral detergent fiber & 13.4 & \\
Acid detergent fiber & &
\end{tabular}

The experiment was conducted for 4 periods of 21 days each, with 14 days for treatment adaptation and feed intake measurements, and the last 7 days were for sample collection of feeds, fecal, and urine. The animals were fed ad libitum with water and mineral blocks available at all times (each $\mathrm{kg}$ of mineral block contains the following: Vitamin A-10,000,000 IU; Vitamin E-70,000 IU; Vitamin D-1,600,000 IU; Fe—50 g; Zn—40 g; $\mathrm{Mn}-40 \mathrm{~g} ; \mathrm{Co}-0.1 \mathrm{~g} ; \mathrm{Cu}-10 \mathrm{~g}$; $\mathrm{Se}-0.1 \mathrm{~g} ; \mathrm{I}-0.5 \mathrm{~g}$ ).

\subsection{Sample Collection and Chemical Analyses}

Feeds and refusals were collected daily during the experimental period and were composited by period prior to chemical analysis. Feeds, fecal, and urine samples were collected during the last seven days of each period. Fecal samples were collected by rectal sampling, the urination of each animal was collected by manual stimulation of the penis. Composited samples were oven-dried and ground (1 $\mathrm{mm}$ screen using a Cyclotech Mill, Tecator, 1093, Hoganes, Sweden) and then analyzed for DM, ash, and CP content [16], and acid-insoluble ash (AIA). AIA was used as an indicator to estimate DM fecal excretion [17]. Fiber fractions (NDF and ADF) were analyzed according to Van Soest et al. [18]. Metabolizable energy (ME) was calculated according to Robinson et al. [19]. Digestible organic matter fermented in the rumen (DOMR) was calculated according to an ARC [20] as follows: DOMR $(\mathrm{kg} / \mathrm{d})=$ digestible organic matter intake $(\mathrm{DOMI}, \mathrm{kg} / \mathrm{d}) \times 0.65$, where $\mathrm{DOMI}=[$ digestibility of organic matter $(\mathrm{kg} / \mathrm{kg} \mathrm{DM}) \times$ organic matter intake $(\mathrm{kg} / \mathrm{d})] / 100$, $1 \mathrm{~kg}$ DOMI = $15.9 \mathrm{MJ} \mathrm{ME} / \mathrm{kg}$ [21].

At the last day of each period, rumen fluid sample and blood were collected at 0 and $4 \mathrm{~h}$ post morning feeding. At each sampling time, approximately $200 \mathrm{~mL}$ of rumen content was collected by an oral-gastric tube (RFE, Drench-Mate, Washington, DC, USA) connected with a vacuum pump (Solida M730, J. Summit Co. Ltd., Bangkok, Thailand) at each time. Rumen fluid was measured for $\mathrm{pH}$ and temperature immediately (Hanna Instrument $\mathrm{HI}$ 8424 Microcomputer, San Francisco, CA, USA). Rumen fluid samples were filtered through four layers of cheesecloth. The first part was used to determine ammonia nitrogen $\left(\mathrm{NH}_{3}-\mathrm{N}\right)$ using the micro-Kjeldahl methods [16]. Rumen fluid samples were used for VFAs analysis using high-performance liquid chromatography (HPLC; Model Water 600; UV detector, Millipore Corp., Milford, MA, USA) [22]. The second part of the filtered fluid sample was 
fixed using a solution of $10 \%$ formalin in sterilized $0.9 \%$ saline. The total direct count of bacteria, protozoa, and fungi was obtained using the method of Galyean [23].

A blood sample (about $10 \mathrm{~mL}$ ) was collected from a jugular vein into tubes with $12 \mathrm{mg}$ of EDTA. Plasma was obtained by centrifuging at $500 \times g$ for $10 \mathrm{~min}$ (Table Top Centrifuge PLC-02, Tustin, CA, USA) and stored at $-20^{\circ} \mathrm{C}$ for later blood urea nitrogen (BUN) [24]. Urine samples were collected to be analyzed for allantoin by HPLC. Samples were then analyzed for urinary allantoin and creatinine. The number of microbial purines absorbed was calculated from purine derivative excretion as described by Chen and Gomes [25]. Microbial crude protein $(\mathrm{MCP})(\mathrm{g} / \mathrm{d})=3.99 \times 0.856 \times \mathrm{mmol}$ of purine derivatives were excreted following the method of Galo et al. [21].

\subsection{Statistical Analysis}

Data were analyzed according to a $4 \times 4$ Latin square design with $2 \times 2$ factorial arrangements of treatments using the General Linear Models procedures [26].

The MIXED procedure [26] was used to analyze data of rumen fluid parameters at different feeding times as repeated measures over time using the following model:

$$
\mathrm{Y}_{i j k}=\mu+\mathrm{D}_{i}+\mathrm{A}_{j}+\mathrm{P}_{i j}+\mathrm{H}_{k}+(\mathrm{DT})_{j k}+\varepsilon_{i j k},
$$

where $Y_{i j k}$ is the observation from animal $j$, receiving diet $i$, in period $k ; \mu$-the overall mean; $\mathrm{D}_{i}$ - effect of treatment $(i=1-4) ; \mathrm{A}_{j}$-the effect of animal $(j=1-4) ; \mathrm{P}_{k}$-the effect of period $(k=1-4) ; \mathrm{H}_{k}$-the effect of time after feeding $(k=1$ and 4$) ;(\mathrm{DT})_{j k}$-the interaction of treatment $\times$ time after feeding; $e_{i j k}$-the residual effect.

Treatment means were compared by Tukey's multiple comparison test. Differences between means with $p<0.05$ were accepted as representing statistically significant differences.

\section{Results and Discussion}

\subsection{Dry Matter Intake and Nutrients Digestibility}

There was no significant interaction effect between the R:C ratio and LY addition on nutrient digestibility. Moreover, DM intake was found to have significant interaction with both the R:C ratio and LY addition (Table 2). Increasing the concentrate proportion increased $(p<0.05)$ DM intake and digestibility of DM, OM, and CP but decreased $(p<0.05)$ NDF and ADF digestibility. These findings agree with Chen et al. [27], cow fed a high concentrate diet showed significantly increased digestibility of nutrients. It could be due to the concentrate diet can provide additional nutrients for rumen microbial growth and can enhance rumen fermentation. The increase in DM and OM due to greater concentrate proportion in the diet is a direct reflex of the greater digestibility of ingredients that conform to the concentrate compared with the digestibility of treated straw [15]. The lower digestibility for fiber fraction (NDF and ADF) could be due to the tendency of a lower ruminal $\mathrm{pH}$ to greater quantities of soluble carbohydrates in these treatments (Table 3). Some strains of $S$. cerevisiae have been shown to enhance rumen bacterial growth and activity with a subsequent effect on NDF digestibility. Moreover, LY increases fibrolytic fungi population, which have been shown to stimulate the breakdown of polysaccharides connected with lignin via esterase secretion $[10,28]$. 
Table 2. Effect of roughage-to-concentrate ratio and live yeast supplementation on voluntary feed intake and nutrient digestibility in Thai native beef cattle.

\begin{tabular}{|c|c|c|c|c|c|c|c|c|}
\hline \multirow{2}{*}{ Items } & \multicolumn{2}{|c|}{$\mathrm{R}: \mathrm{C}$ at $60: 40$} & \multicolumn{2}{|c|}{$\mathrm{R}: \mathrm{C}$ at $40: 60$} & \multirow{2}{*}{ SEM } & \multicolumn{3}{|c|}{ Interaction } \\
\hline & LY 0 & LY 4 & LY 0 & LY 4 & & R:C & LY & $\mathbf{R}: \mathbf{C} \times \mathbf{L Y}$ \\
\hline \multicolumn{9}{|l|}{ Dry matter intake } \\
\hline $\mathrm{kg} / \mathrm{d}$ & 2.5 & 3.1 & 2.6 & 3.3 & 0.09 & 0.048 & 0.036 & 0.042 \\
\hline $\mathrm{g} / \mathrm{kg}$ BW0.75 & 83.7 & 85.8 & 84.3 & 88.6 & 1.24 & 0.050 & 0.041 & 0.051 \\
\hline \multicolumn{9}{|l|}{ Estimate energy intake } \\
\hline $\mathrm{ME}, \mathrm{MJ} / \mathrm{d}$ & 25.6 & 33.1 & 27.3 & 36.5 & 0.82 & 0.042 & 0.039 & 0.971 \\
\hline $\mathrm{ME}, \mathrm{MJ} / \mathrm{kgDM}$ & 10.2 & 10.7 & 10.5 & 11.1 & 0.98 & 0.024 & 0.031 & 0.852 \\
\hline \multicolumn{9}{|l|}{ Nutrient digestibility, \% } \\
\hline Dry matter & 61.5 & 66.4 & 64.8 & 68.5 & 0.01 & 0.048 & 0.040 & 0.635 \\
\hline Organic matter & 64.4 & 67.1 & 66.1 & 69.6 & 0.04 & 0.021 & 0.035 & 0.664 \\
\hline Crude protein & 64.5 & 66.8 & 67.5 & 69.4 & 0.03 & 0.029 & 0.042 & 0.814 \\
\hline Neutral detergent fiber & 60.1 & 66.2 & 58.3 & 63.7 & 0.04 & 0.047 & 0.015 & 0.385 \\
\hline Acid detergent fiber & 51.6 & 55.2 & 44.1 & 47.6 & 0.05 & 0.030 & 0.022 & 0.638 \\
\hline
\end{tabular}

$\mathrm{R}: \mathrm{C}$ ratio $=$ roughage-to-concentrate ratio; $\mathrm{LY} 0=$ unsupplementation of live yeast; $\mathrm{LY} 4=$ supplementation live yeast at $4 \mathrm{~g} / \mathrm{hd} / \mathrm{d} ; \mathrm{SEM}=$ standard error of the mean. Metabolizable energy (ME) was calculated according to the equation described by Robinson et al. [19]. Digestible organic matter fermented in the rumen (DOMR) was calculated according to the equation described by ARC [20] as follows: DOMR $(\mathrm{kg} / \mathrm{d})=$ digestible organic matter intake $(\mathrm{DOMI}, \mathrm{kg} / \mathrm{d}) \times 0.65$, where DOMI $=$ [digestibility of organic matter $(\mathrm{kg} / \mathrm{kg} \mathrm{DM}) \times$ organic matter intake $(\mathrm{kg} / \mathrm{d})] / 100,1 \mathrm{~kg}$ DOMI $=15.9 \mathrm{MJ} \mathrm{ME} / \mathrm{kg}[21]$.

Table 3. Effect of concentrate level and live yeast supplementation on fermentation characteristics and blood urea nitrogen in Thai native beef cattle.

\begin{tabular}{|c|c|c|c|c|c|c|c|c|}
\hline \multirow{2}{*}{ Items } & \multicolumn{2}{|c|}{$\mathrm{R}: C$ at $60: 40$} & \multicolumn{2}{|c|}{$\mathrm{R}: \mathrm{C}$ at $40: 60$} & \multirow{2}{*}{ SEM } & \multicolumn{3}{|c|}{ Interaction } \\
\hline & LY 0 & LY 4 & LY 0 & LY 4 & & $\mathrm{R}: \mathrm{C}$ & LY & $\mathbf{R}: \mathbf{C} \times \mathbf{L Y}$ \\
\hline Ruminal pH & 6.5 & 6.6 & 6.3 & 6.3 & 0.19 & 0.050 & 0.058 & 0.463 \\
\hline Temperature, ${ }^{\circ} \mathrm{C}$ & 38.8 & 39.1 & 39.1 & 39.3 & 0.15 & 0.341 & 0.305 & 0.221 \\
\hline $\mathrm{NH}_{3}-\mathrm{N}, \mathrm{mg} / \mathrm{dL}$ & 12.3 & 14.6 & 15.8 & 16.9 & 0.43 & 0.028 & 0.015 & 0.659 \\
\hline BUN, mg/dL & 10.4 & 10.7 & 11.6 & 11.8 & 0.26 & 0.543 & 0.612 & 0.802 \\
\hline Total VFAs, mmol/L & 92.4 & 102.1 & 95.5 & 105.0 & 1.35 & 0.031 & 0.039 & 0.726 \\
\hline \multicolumn{9}{|l|}{ VFAs, $\mathrm{mol} / 100 \mathrm{~mol}$} \\
\hline Acetic acid $\left(C_{2}\right)$ & 67.6 & 65.6 & 64.2 & 62.1 & 0.43 & 0.024 & 0.015 & 0.908 \\
\hline Propionic acid $\left(C_{3}\right)$ & 23.0 & 24.1 & 25.6 & 28.7 & 0.82 & 0.015 & 0.014 & 0.423 \\
\hline Butyric acid $\left(\mathrm{C}_{4}\right)$ & 9.4 & 10.3 & 10.2 & 9.2 & 0.35 & 0.678 & 0.779 & 0.706 \\
\hline $\mathrm{C}_{2}: \mathrm{C}_{3}$ & 2.9 & 2.7 & 2.5 & 2.2 & 1.15 & 0.611 & 0.048 & 0.658 \\
\hline
\end{tabular}

$\mathrm{R}: \mathrm{C}$ ratio = roughage-to-concentrate ratio; LY $0=$ unsupplementation of live yeast; $\mathrm{LY} 4=$ supplementation live yeast at $4 \mathrm{~g} / \mathrm{hd} / \mathrm{d}$; $\mathrm{SEM}=$ standard error of the mean; $\mathrm{NH}_{3}-\mathrm{N}=$ ammonia nitrogen; $\mathrm{BUN}=$ blood urea nitrogen; VFAs $=$ volatile fatty acids.

It has been proposed that consumption can be lowered in diets with increased $\mathrm{R}: \mathrm{C}$ ratios due to the negative relationship between forage NDF and diet bulk density $[5,29]$. However, increasing the proportion of concentrate in the diet had an influence on DM intake, according to the current findings.

The DM intake and digestibility of DM, OM, CP, NDF, and ADF increased with the addition of LY. Maximum digestibility of NDF and ADF was achieved at the R:C ratio of 40:60 and the addition of LY at $4 \mathrm{~g} / \mathrm{hd} / \mathrm{d}$. Similarly, Guedes et al. [30] stated that the addition of LY improved the fiber degradation of maize silage in cows. Mir and Mir [31] found that adding S. cerevisiae enhanced the digestibility of DM. Furthermore, adding dry LY to growing and finishing beef calves at a rate of $10 \mathrm{~g} / \mathrm{d}$ improved DM and NDF digestibility [32]. The addition of $S$. cerevisiae improved nutrient digestibility, and this could be attributed to the rumen microbe being stimulated to a greater rate of feed digestion. Furthermore, S. cerevisiae reduces fluctuations in ruminal $\mathrm{pH}$ and redox potential in high proportion of concentrate diet, resulting in more stable rumen environment for fibrolytic bacteria growth [33]. Resulted in greater amount of fiber digested, it indicates that LY 
addition increased both rates of fiber digestion and passage, resulting for higher intake and total digestibility $[32,34]$.

A less acidic, more anaerobic ruminal environment might aid fiber-degrading microorganism proliferation and increase fiber decomposition in the rumen [4]. The addition of LY improved OM digestibility, and the advantages increased as the dietary NDF concentration increased. LY is hypothesized to improve animal performance by altering the rumen microbiota to promote the growth and activity of fibrolytic microbes as well as those that metabolize lactate. This could be useful in diets that encourage enhanced short-chain fatty acid synthesis in the rumen, resulting in lower rumen $\mathrm{pH}$. Dias et al. [35] discovered that supplementing with $S$. cerevisiae reduced the rate of starch digestion in the rumen in cows with higher DM consumption, which could result in a more stable rumen ecology.

\subsection{Ruminal Parameters and Blood Metabolite}

An interaction effect was not found between the R:C ratio and the LY addition on ruminal parameters and BUN concentrations (Table 3). All treatments had pH levels ranging from 6.3 to 6.6. However, the results showed that as the number of concentrates in the diet increased, ruminal $\mathrm{pH}$ declined, and it was lowest when the $\mathrm{R}: \mathrm{C}$ ratio was 40:60. Ruminal $\mathrm{pH}$ was found to be steady between 6.3 and 6.6, and ruminal temperature was found to be between 38.8 and $39.3^{\circ} \mathrm{C}$. However, Ramos et al. [36] discovered that diets high in concentrate typically resulted in a significant decrease in ruminal $\mathrm{pH}, \mathrm{a}$ decreased digestion rate, and decreased cellulolytic bacteria activity. Ruminal $\mathrm{pH}$ and its daily fluctuations can be considered a major factor in the occurrence of SARA and the regulation of microbial activity. Ruminal $\mathrm{pH}$ is a good indicator of the rumen environment's internal homeostasis; thus, maintaining a steady stable ruminal $\mathrm{pH}$ is critical for good rumen ecology, fermentation, and microbial development. In general, lower lactic acid levels in the rumen are associated with $\mathrm{pH}$ stabilization. Moreover, an increase in ruminal $\mathrm{pH}$ could be caused by a decrease in lactic acid concentration due to ability of LY to enhance lactic-acid-utilizing bacteria (Selenomonas ruminantium and Megasphaera elsdenii) [4,11,32]. Furthermore, the addition of $\mathrm{LY}$ enhanced ruminal $\mathrm{pH}$ and cellulolytic bacteria $[6,30,35]$.

Ammonia is the primary nitrogen source for microbial protein synthesis, and bacteria can grow using $\mathrm{NH}_{3}-\mathrm{N}$ as the main nitrogen source. The $\mathrm{NH}_{3}-\mathrm{N}$ content in the current study ranged from 12.3 to $16.9 \mathrm{mg} / \mathrm{dL}$. In the $\mathrm{R}: \mathrm{C}$ ratio of 40:60, the $\mathrm{NH}_{3}-\mathrm{N}$ was greatest. This could be because a greater $\mathrm{CP}$ from a high-concentrate feed ratio may provide more microbial degradation into high concentrations of $\mathrm{NH}_{3}-\mathrm{N}$ than a low-ratio concentrate diet. A concentration of $\mathrm{NH}_{3}-\mathrm{N}$ in the range of 15 to $30 \mathrm{mg} / \mathrm{dL}$ may improve voluntary feed intake, microbial protein synthesis, nutrient digestibility, and rumen ecology, whereas an $\mathrm{NH}_{3}-\mathrm{N}$ deficit decreases the bacterial growth rate [37-39]. The greater concentration of ruminal $\mathrm{NH}_{3}-\mathrm{N}$ in the high-concentrate diet was attributed to the dynamic equilibrium between $\mathrm{NH}_{3}-\mathrm{N}$ production and use by rumen bacteria. The presence of high levels of $\mathrm{NH}_{3}-\mathrm{N}$ in the rumen shows that animals may be receiving adequate accessible nitrogen content from dietary intake, most likely as a result of the high concentrate content of the cow diet [36]. However, the addition of $\mathrm{LY}$ significantly enhanced the $\mathrm{NH}_{3}-\mathrm{N}$ content $(p<0.05)$, contrary to the findings of Li et al. [33], who showed that the addition of S. cerevisiae had no effect on the $\mathrm{NH}_{3}-\mathrm{N}$ concentration in the rumen. According to Kumprechtova et al. [39], lower $\mathrm{NH}_{3}-\mathrm{N}$ concentrations could be due to increased cellulolytic bacteria number, as this type of bacteria primarily uses $\mathrm{NH}_{3}-\mathrm{N}$ as a $\mathrm{N}$ source. The drop in ruminal $\mathrm{NH}_{3}-\mathrm{N}$ content appeared to be related to increased $\mathrm{NH}_{3}-\mathrm{N}$ absorption into microbial proteins, most likely as a result of $S$. cerevisiae stimulating microbial activity [40]. The decrease in LY supplied to cattle rumen appears to be related to $\mathrm{NH}_{3}-\mathrm{N}$ incorporation into microbial protein [41], or it could be due to LY's inhibitory influence on proteolysis [42,43].

On total VFA and VFA profiles, there was no interaction effect between the R:C ratio and LY addition (Table 3). The total VFA concentrations in all treatments varied from 92.4 to $105.0 \mathrm{mmol} / \mathrm{L}$, which was consistent with the findings of Cagle et al. [32] and Kumprechtova et al. [39]. The increased amount of concentrate in diet raised total VFA and 
$C_{3}$, while decreasing $C_{2}$ and $C_{2}$-to- $C_{3}$ ratios $(p<0.05)$. This could be owing to the presence of highly degradable carbohydrates, particularly starch, in the concentrate.

Dias et al. [35] discovered that dairy cows fed S. cerevisiae had greater total VFA and $C_{3}$ concentrations. The addition of $S$. cerevisiae to the rumen also changed the molar proportion of VFA in the rumen-particularly, the $C_{3}$ concentration-resulting in an increase in the ruminant's glucogenic potential. Wang et al. [38] examined the addition of S. cerevisiae to in vitro gas fermentation and found no change in the $C_{2}$ to $C_{3}$ ratio. This difference may be impacted by different yeast strains and the types of diets utilized in various tests [9]. The addition of LY to the rumen may have enhanced the microbial population in the rumen, resulting in better carbohydrate fermentation into VFAs. The ability of LY in the rumen could aid in the formation of lactate-consuming and cellulolytic bacterial populations, hence aiding in rumen stabilization and boosting the rumen's capability to digest fiber $[10,44]$. Dietary composition has the greatest influence on volatile fatty acid content; manipulating the diet by increasing the level of concentrate diet is a strategy to improve ruminal fermentation by increasing propionogenesis [45]. Such a typical propionic acid fermentation reaction was found in the current investigation, and as a result, the $C_{2}: C_{3}$ ratio decreased, which is consistent with prior findings [4,46-48]. This increase in $C_{3}$ concentration can be attributed to increased nonfiber carbohydrate consumption.

\subsection{Microbial Population and Microbial Protein Synthesis}

In the current study, there were no interactions between the $\mathrm{R}: \mathrm{C}$ ratio and the addition of LY on microbial population (Table 4). Total bacterial direct counts and fungal zoospores were increased $(p<0.05)$ in a high-concentrate diet, whereas protozoal populations were not changed $(p>0.05)$. The changes in the rumen microbial population are expected to stimulate the digestion of carbohydrates in the rumen, which likely explains the increased rumen NDF digestion in the present experiment and the digestion of OM. This is in agreement with Histrov et al. [49], reported that there was more carbohydrate for microbial fermentation and incorporation of $\mathrm{NH}_{3}-\mathrm{N}$ into microbial cells with increased feed intake. However, Ramos et al. [36] reported that the high-concentrate diet reduced the richness and diversity of the rumen microbiota. The total population of protozoa in ruminal fluid normally enhances with the high proportion of concentrate diet $[3,50]$.

Table 4. Effect of concentrate level and live yeast supplementation on microbial population in Thai native beef cattle.

\begin{tabular}{|c|c|c|c|c|c|c|c|c|}
\hline \multirow{2}{*}{ Items } & \multicolumn{2}{|c|}{$\mathrm{R}: \mathrm{C}$ at $60: 40$} & \multicolumn{2}{|c|}{$\mathrm{R}: \mathrm{C}$ at $40: 60$} & \multirow{2}{*}{ SEM } & \multicolumn{3}{|c|}{ Interaction } \\
\hline & LY 0 & LY 4 & LY 0 & LY 4 & & $\mathrm{R}: \mathrm{C}$ & LY & $\mathbf{R}: \mathbf{C} \times \mathbf{L Y}$ \\
\hline Ruminal microbes & & & & & & & & \\
\hline Bacteria, $\times 10^{11}$ cell $/ \mathrm{ml}$ & 4.8 & 5.4 & 5.0 & 5.7 & 0.24 & 0.044 & 0.041 & 0.949 \\
\hline Protozoa, $\times 10^{6} \mathrm{cell} / \mathrm{ml}$ & 5.0 & 3.9 & 5.6 & 4.2 & 0.41 & 0.843 & 0.039 & 0.536 \\
\hline Fungi, $\times 10^{5}$ cell $/ \mathrm{ml}$ & 2.8 & 3.9 & 3.4 & 4.5 & 0.35 & 0.845 & 0.032 & 0.961 \\
\hline
\end{tabular}

$\mathrm{R}: \mathrm{C}$ ratio $=$ roughage-to-concentrate ratio; $\mathrm{LY} 0=$ unsupplementation of live yeast; $\mathrm{LY} 4=$ supplementation live yeast at $4 \mathrm{~g} / \mathrm{hd} / \mathrm{d}$; SEM $=$ standard error of the mean.

According to the findings, the population of total bacteria and fungi increased $(p<0.05)$ while protozoal decreased $(p<0.05)$ with LY addition. It could be because LY supplementation may give growth factors such as organic acid or vitamins, which may boost the population of cellulolytic bacteria. Li et al. [33] revealed that the addition of LY to dairy cows has increased the relative abundance of microorganisms used for cellulolytic, amylolytic, and lactate use.

The results of the present study showed that microbial nitrogen supply (MNS) and efficiency of microbial nitrogen synthesis (EMNS) were increased in cattle receiving the greater concentrate proportion and with LY supplementation $(p<0.05)$ (Table 5). Rumen $\mathrm{NH}_{3}-\mathrm{N}$ from protein degradation would be incorporated for microbial protein synthesis. Nitrogen absorption and retention are good indicators of ruminant utilization [25]. Dias 
et al. [35] showed that rumen microbial protein synthesis was an effective indicator of nitrogen utilization. Furthermore, a close relationship between the protein and the carbohydrate is essential for effective utilization. However, in this study, LY supplementation significantly improved the $\mathrm{N}$ absorption, $\mathrm{N}$ retention, and EMNS. Moreover, Erasmus et al. [43] observed an increase in the efficiency of the synthesis of microbial proteins in response to $S$. cerevisiae addition. When the cows were fed LY, especially when mixed with the high-concentrate diet, this was linked to lactate utilizing bacteria, an increase in cellulolytic bacteria, and flow of MNS from the rumen. Cows fed a high-nonfiber-carbohydrate diet had increased microbial protein yield when supplemented with $S$. cerevisiae, as reported by Hristov et al. [49]. Furthermore, Dias et al. [35] discovered that cows fed high starch and LY supplementation had the highest microbial $\mathrm{N}$ output, and that the concentration of $\mathrm{NH}_{3}-\mathrm{N}$ in dairy cows fed diet with the high-starch content was lower than cows provided the low starch diet.

Table 5. Effect of concentrate level and live yeast supplementation on urinary purine derivatives (PD) and microbial protein synthesis in Thai native beef cattle.

\begin{tabular}{|c|c|c|c|c|c|c|c|c|}
\hline \multirow{2}{*}{ Items } & \multicolumn{2}{|c|}{$\mathrm{R}: \mathrm{C}$ at $60: 40$} & \multicolumn{2}{|c|}{$\mathrm{R}: \mathrm{C}$ at $40: 60$} & \multirow{2}{*}{ SEM } & \multicolumn{3}{|c|}{ Interaction } \\
\hline & LY 0 & LY 4 & LY 0 & LY 4 & & $\mathrm{R}: \mathrm{C}$ & LY & $\mathbf{R}: \mathbf{C} \times \mathbf{L Y}$ \\
\hline Urinary purine derivatives, $\mathrm{m}$ & & & & & & & & \\
\hline Allantoin excretion & 17.9 & 21.5 & 20.3 & 24.6 & 4.39 & 0.023 & 0.036 & 0.509 \\
\hline Allantoin absorption & 49.6 & 56.4 & 53.8 & 62.9 & 2.14 & 0.041 & 0.043 & 0.084 \\
\hline MNS, $\mathrm{gN} / \mathrm{d}$ & 31.6 & 35.4 & 33.9 & 38.6 & 2.03 & 0.044 & 0.042 & 0.751 \\
\hline EMNS, g/kg OMDR & 12.5 & 16.1 & 15.6 & 18.2 & 1.06 & 0.045 & 0.043 & 0.216 \\
\hline
\end{tabular}

$\mathrm{R}: \mathrm{C}$ ratio $=$ roughage-to-concentrate ratio; $\mathrm{LY} 0=$ unsupplementation of live yeast; $\mathrm{LY} 4=$ supplementation live yeast at $4 \mathrm{~g} / \mathrm{hd} / \mathrm{d}$; SEM = standard error of the mean; MNS = microbial nitrogen supply; EMNS = efficiency of microbial nitrogen synthesis; OMDR = digestible organic matter apparently fermented in the rumen.

Furthermore, the presence of LY in the rumen increases microbial growth, resulting in increased microbial protein transport to the duodenum. In general, yeast supplementation modifies the rumen microbiome population, resulting in improved VFA production and greater microbial protein synthesis $[42,46,50]$. When cows were fed S. cerevisiae at a rate of $56 \mathrm{~g} / \mathrm{hd} / \mathrm{d}$, microbial protein synthesis increased by 9.3 percent [49]. A decrease in protozoal populations in response to $S$. cerevisiae fermentation product supplementation, according to Zhu et al. [46], may reduce bacterial preying and allow more microbial protein to reach the small intestine. It has been found that $S$. cerevisiae supplementation reduced the amount of Entodinium in steers $26.0 \%$. Entodinium can engulf bacteria and reduce the passage of microbial protein to the small intestine [51,52].

\section{Conclusions and Recommendations}

In conclusion, in Thai native beef cattle fed urea-calcium-hydroxide-treated rice straw as a roughage source, a $\mathrm{R}: \mathrm{C}$ ratio of 40:60 and $\mathrm{LY}$ of $4 \mathrm{~g} / \mathrm{hd} / \mathrm{d}$ resulted in controlled ruminal $\mathrm{pH}$, increased nutrient digestibility of $\mathrm{DM}, \mathrm{OM}, \mathrm{CP}$, and ruminal VFA productionparticularly, $\mathrm{C}_{3}$ - and EMNS while decreasing protozoal population.

Author Contributions: Conceptualization, K.P.; formal analysis, K.P.; investigation, K.P.; methodology, K.P. and B.P.; writing—original draft, K.P.; writing—review and editing, K.P., M.W. and A.C. All authors have read and agreed to the published version of the manuscript.

Funding: The authors would like to express their most sincere thanks to Program Management Unit on Area Based Development-PMU-A (A13F640053), Officer of National Higher Education Science Research and Innovation Policy Council, Thailand, and the Research Program on the Research and Development of Winged Bean Root Utilization as Ruminant Feed and the Increase Production Efficiency and Meat Quality of Native Beef and Buffalo Research Group from KKU. 
Institutional Review Board Statement: Animal involved in this study were approved by the Animal Ethics Committee of Nakhon Phanom University (AENPU A2/2560), based on the Ethics of Animal Experimentation of National Research Council of Thailand.

Informed Consent Statement: Not applicable.

Data Availability Statement: Not applicable.

Acknowledgments: We also express our appreciation to the Tropical Feed Resources Research and Development Centre (TROFREC), Khon Kaen University (KKU), Department of Animal Science, Faculty of Agriculture and Technology, Nakhon Phanom University.

Conflicts of Interest: The authors declare that they have no conflict of interest.

\section{References}

1. Ogata, T.; Kim, Y.H.; Masaki, T.; Iwamoto, E.; Ohtani, Y.; Orihashi, T.; Ichijo, T.; Sato, S. Effects of an increased concentrate diet on rumen $\mathrm{pH}$ and the bacterial community in Japanese black beef cattle at different fattening stages. J. Vet. Med. Sci. 2019, 81, 968-974. [CrossRef] [PubMed]

2. Mao, H.L.; Mao, H.L.; Wang, J.K.; Liu, J.X.; Yoon, I. Effects of Saccharomyces cerevisiae fermentation product on in vitro fermentation and microbial communities of low-quality forages and mixed diets. J. Anim. Sci. 2013, 91, 3291-3298. [CrossRef] [PubMed]

3. Amin, A.B.; Mao, S. Influence of yeast on rumen fermentation, growth performance and quality of products in ruminants: Review. Anim. Nutr. 2021, 7, 31-41. [CrossRef] [PubMed]

4. Sousa, D.O.; Oliveira, C.A.; Velasquez, A.V.; Souza, J.M.; Chevaux, E.; Mari, L.J.; Silva, L.F.P. Live yeast supplementation improves rumen fibre degradation in cattle grazing tropical pastures throughout the year. Anim. Feed Sci. Technol. 2018, 236, 149-158. [CrossRef]

5. Magrin, L.; Gottardo, F.; Fiore, E.; Gianesella, M.; Martin, B.; Chevaux, E.; Cozzi, G. Use of live yeast train of Saccharomyces cerevisiae in a high-concentrate diet to finishing Charolais bulls: Effects on growth, slaughter performance, behavior, and rumen environment. Anim. Feed Sci. Technol. 2018, 241, 84-93. [CrossRef]

6. Dehghan-Banadaky, M.; Ebrahimi, M.; Motameny, R.; Heidari, S.R. Effects of live yeast supplementation on mid-lactation dairy cows performances, milk composition, rumen digestion and plasma metabolites during hot season. J. App. Anim. Res. 2013, 41, 137-142. [CrossRef]

7. AlZahal, O.; Li, F.; Guan, L.L.; Walker, N.D.; McBride, B.W. Factors influencing ruminal bacterial community diversity and composition and microbial fibrolytic enzyme abundance in lactating dairy cows with a focus on the role of active dry yeast. $J$. Dairy Sci. 2017, 100, 4377-4393. [CrossRef] [PubMed]

8. Ran, T.; Shen, Y.; Saleem, A.M.; AlZahal, O.; Beauchemin, K.A.; Yang, W. Using ruminally protected and nonprotected active dried yeast as alternatives to antibiotics in finishing beef steers: Growth performance, carcass traits, blood metabolites, and fecal Escherichia coli. J. Anim. Sci. 2018, 96, 4385-4397. [CrossRef] [PubMed]

9. Ding, G.; Chang, Y.; Zhao, L.; Zhou, Z.; Ren, L.; Meng, Q. Effect of Saccharomyces cerevisiae on alfalfa nutrient degradation characteristics and rumen microbial populations of steers fed diets with different concentrate-to-forage ratios. J. Anim. Sci. Biotechnol. 2014, 5, 24. [CrossRef] [PubMed]

10. Chaucheyras-Durand, F.; Walker, N.D.; Bach, A. Effects of active dry yeasts on the rumen microbial ecosystem: Past, present and future. Anim. Feed Sci. Technol. 2008, 145, 5-26. [CrossRef]

11. Crossland, W.L.; Cagle, C.M.; Sawyer, J.E.; Callaway, T.R.; Tedeschi, L.O. Evaluation of active dried yeast in the diets of feedlot steers. II. effects on rumen $\mathrm{pH}$ and liver health of feedlot steers. J. Anim. Sci. 2019, 97, 1347-1363. [PubMed]

12. Mombach, M.A.; Cabral, L.S.; Lima, L.R.; Ferreira, D.C.; Pedreira, C.B.; Pereira, D.H. Correction to: Association of ionophores, yeast, and bacterial probiotics alters the abundance of ruminal microbial species of pasture intensively finished beef cattle. Trop. Anim. Health Prod. 2021, 53, 401. [CrossRef] [PubMed]

13. Broadway, P.; Carroll, J.; Sanchez, N. Live yeast and yeast cell wall supplements enhance immune function and performance in food-producing livestock: A review. Microorganisms 2015, 3, 417-427. [CrossRef] [PubMed]

14. Vallejo-Hernandez, L.H.; Elghandour, M.M.Y.; Greiner, R.; Anele, U.Y.; Rivas-Caceres, R.R.; Barros-Rodriguez, M.; Salem, A.Z.M. Environmental impact of yeast and exogenous xylanase on mitigating carbon dioxide and enteric methane production in ruminants. J. Clean. Prod. 2018, 189, 40-46. [CrossRef]

15. Phesatcha, K.; Phesatcha, B.; Wanapat, M.; Cherdthong, A. Roughage to concentrate ratio and Saccharomyces cerevisiae inclusion could modulate feed digestion and in vitro ruminal fermentation. Vet. Sci. 2020, 7, 151. [CrossRef] [PubMed]

16. Association of Official Analytical Chemists (AOAC). Official Methods of Analysis, 19th ed.; AOAC International: Gaithersburg, MD, USA, 2012.

17. Van Keulen, J.Y.; Young, B.A. Evaluation of acid-insoluble ash as a natural marker in ruminant digestibility studies. J. Anim. Sci. 1977, 44, 282-287. [CrossRef]

18. Van Soest, P.J.; Robertson, J.B.; Lewis, B.A. Methods for dietary fiber, neutral detergent fiber, and nonstarch polysaccharides in relation to animal nutrition. J. Dairy Sci. 1991, 74, 3583-3597. [CrossRef] 
19. Robinson, P.H.; Givens, D.I.; Getachew, G. Evaluation of NRC, UC Davis and ADAS approaches to estimate the metabolizable energy values of feeds at maintenance energy intake from equations utilizing chemical assays and in vitro determinations. Anim. Feed Sci. Technol. 2004, 114, 75-90. [CrossRef]

20. ARC. Nutrient Requirements of the Ruminants Livestock (Supplement No. 1); Commonwealth Agricultural Bureaux: Slough, UK, 1984.

21. Kearl, L.C. Nutrient Requirements of Ruminants in Developing Countries; International Feedstuffs Institute, Utah State University: Logan, UT, USA, 1982.

22. Galo, E.; Emanuele, S.M.; Sniffen, C.J.; White, J.H.; Knapp, J.R. Effects of a polymer-coated urea product on nitrogen metabolism in lactating Holstein dairy cattle. J. Dairy Sci. 2003, 86, 2154-2162. [CrossRef]

23. Galyean, M. Laboratory Procedure in Animal Nutrition Research; Department of Animal and Range Sciences, New Mexico State University: Las Cruces, NM, USA, 1989; Volume 188.

24. Crocker, C.L. Rapid Determination of urea nitrogen in serum or plasma without deproteinization. Am. J. Med. Technol. 1967, 33, 361-365. [PubMed]

25. Chen, X.B.; Gomes, M.J. Estimation of microbial protein supply to sheep and cattle based on urinary excretion of purine derivatives. In An Overview of the Technical Details; Occasional Publication; International Feed Resources Unit, Rowett Research Institute: Aberdeen, Scotland, UK, 1992.

26. SAS (Statistical Analysis System). User's Guide: Statistic, 9.3th ed.; SAS Inst. Inc.: Cary, NC, USA, 2013.

27. Chen, H.; Wang, C.; Huasai, S.; Chen, A. Effect of dietary forage to concentrate ratio on nutrient digestibility, ruminal fermentation and rumen bacterial composition in Angus cows. Sci. Rep. 2021, 11, 17023. [CrossRef] [PubMed]

28. Lopez-Soto, M.A.; Valdes-Garcia, Y.S.; Plascencia, A.; Castro-Perez, B.I.; Estrada-Angulo, A. Influence of feeding live yeast on microbial protein synthesis and nutrient digestibility in steers fed a steam-flaked corn-based diet. Acta. Scand. A Anim. Sci. 2013, 63, 39-46. [CrossRef]

29. Muñoz, C.; Wills, D.A.; Yan, T. Effects of dietary active dried yeast (Saccharomyces cerevisiae) supply at two levels of concentrate on energy and nitrogen utilisation and methane emissions of lactating dairy cows. Anim. Prod. Sci. 2017, 57, 656-664. [CrossRef]

30. Guedes, C.M.; Gonçalves, D.; Rodrigues, M.A.M.; Dias-da-Silva, A. Effects of a Saccharomyces cerevisiae yeast on ruminal fermentation and fibre degradation of maize silages in cows. Anim. Feed Sci. Technol. 2008, 145, 27-40. [CrossRef]

31. Mir, Z.; Mir, P.S. Effect of the addition of live yeast (Saccharomyces cerevisiae) on growth and carcass quality of steers fed high-forage or high-grain diets and on feed digestibility and in situ degradability. J. Anim. Sci. 1994, 72, 537-545. [CrossRef] [PubMed]

32. Cagle, C.M.; Fonseca, M.A.; Callaway, T.R.; Runyan, C.A.; Cravey, M.D.; Tedeschi, L.O. Evaluation of the effects of live yeast on rumen parameters and in situ digestibility of dry matter and neutral detergent fiber in beef cattle fed growing and finishing diets. Appl. Anim. Sci. 2020, 36, 36-47. [CrossRef]

33. Li, Y.; Shen, Y.; Niu, J.; Guo, Y.; Pauline, M.; Zhao, X.; Li, Q.; Cao, Y.; Bi, C.; Zhang, X.; et al. Effect of active dry yeast on lactation performance, methane production, and ruminal fermentation patterns in early-lactating Holstein cows. J. Dairy Sci. 2021, 104, 381-390. [CrossRef]

34. Khalouei, H.; Seranatne, V.; Fehr, K.; Guo, J.; Yoon, I.; Khafipour, E.; Plaizier, J.C. Effects of Saccharomyces cerevisiae fermentation products and subacute ruminal acidosis on feed intake, fermentation, and nutrient digestibilities in lactating dairy cows. Can. J. Anim. Sci. 2021, 101, 143-157. [CrossRef]

35. Dias, A.L.G.; Freitas, J.A.; Micai, B.; Azevedo, R.A.; Greco, L.F.; Santos, J.E.P. Effect of supplemental yeast culture and dietary starch content on rumen fermentation and digestion in dairy cows. J. Dairy Sci. 2018, 101, 201-221. [CrossRef]

36. Ramos, S.C.; Jeong, C.D.; Mamuad, L.L.; Kim, S.H.; Kang, S.H.; Kim, E.T.; Cho, Y.I.; Lee, S.S.; Lee, S.S. Diet transition from highforage to high-concentrate alters rumen bacterial community composition, epithelial transcriptomes and ruminal fermentation parameters in dairy cows. Animals 2021, 11, 838. [CrossRef]

37. Wanapat, M.; Pimpa, O. Effect of ruminal $\mathrm{NH}_{3}-\mathrm{N}$ levels on ruminal fermentation, purine derivatives, digestibility and rice straw intake in swamp buffaloes. Asian-Australas. J. Anim. Sci. 1999, 12, 904-907. [CrossRef]

38. Wang, Z.; He, Z.; Beauchemin, K.A.; Tang, S.; Zhou, C.; Han, X.; Wang, M.; Kang, J.; Odongo, N.E.; Tan, Z. Evaluation of different yeast species for improving in vitro fermentation of cereal straws. Asian-Australas. J. Anim. Sci. 2016, 29, 230-240. [CrossRef] [PubMed]

39. Kumprechtová, D.; Illek, J.; Julien, C.; Homolka, P.; Jančík, F.; Auclair, E. Effect of live yeast (Saccharomyces cerevisiae) supplementation on rumen fermentation and metabolic profile of dairy cows in early lactation. J. Anim. Physiol. Anim. Nutr. 2019, 103, 447-455. [CrossRef] [PubMed]

40. McAllister, T.A.; Beauchemin, K.A.; Alazzeh, A.Y.; Baah, J.; Teather, R.M.; Stanford, K. Review: The use of direct fed microbials to mitigate pathogens and enhance production in cattle. Can. J. Anim. Sci. 2011, 91, 193-211. [CrossRef]

41. Sartori, E.D.; Canozzi, M.E.A.; Zago, D.; Prates, Ê.R.; Velho, J.P.; Barcellos, J.O.J. The effect of live yeast supplementation on beef cattle performance: A systematic review and meta-analysis. J. Agric. Sci. 2017, 9, 21. [CrossRef]

42. Enjalbert, F.; Garrett, J.E.; Moncoulon, R.; Bayourthe, C.; Chicoteau, P. Effects of yeast culture (Saccharomyces cerevisiae) on ruminal digestion in non-lactating dairy cows. Anim. Feed Sci. Technol. 1999, 76, 195-206. [CrossRef]

43. Erasmus, L.J.; Botha, P.M.; Kistner, A. Effect of yeast culture supplement on production, rumen fermentation, and duodenal nitrogen flow in dairy cows. J. Dairy Sci. 1992, 75, 3056-3065. [CrossRef] 
44. Zhu, W.; Wei, Z.; Xu, N.; Yang, F.; Yoon, I.; Chung, Y.; Liu, J.; Wang, J. Effects of Saccharomyces cerevisiae fermentation products on performance and rumen fermentation and microbiota in dairy cows fed a diet containing low quality forage. J. Anim. Sci. Biotechnol. 2017, 8, 36. [CrossRef]

45. Monnerat, J.P.I.; Dos, S.; Paulino, P.V.R.; Detmann, E.; Valadares Filho, S.C.; Valadares, R.D.F.; Duarte, M.S. Effects of Saccharomyces cerevisiae and monensin on digestion, ruminal parameters, and balance of nitrogenous compounds of beef cattle fed diets with different starch concentrations. Trop. Anim. Health Prod. 2013, 45, 1251-1257. [CrossRef]

46. Suriyapha, C.; Cherdthong, A.; Suntra, C.; Polyorach, S. Utilization of yeast waste fermented citric waste as a protein source to replace soybean meal and various roughage to concentrate ratios on in vitro rumen fermentation, gas kinetic, and feed digestion. Fermentation 2021, 7, 120. [CrossRef]

47. Suntara, C.; Cherdthong, A.; Uriyapongson, S.; Wanapat, M.; Chanjula, P. Novel Crabtree negative yeast from rumen fluids can improve rumen fermentation and milk quality. Sci. Rep. 2021, 11, 6236. [CrossRef] [PubMed]

48. Cherdthong, A.; Supapong, C. Improving the nutritive value of cassava bioethanol waste using fermented yeast as a partial replacement of protein source in dairy calf ration. Trop. Anim. Health Prod. 2019, 51, 2139-2144. [CrossRef]

49. Hristov, A.N.; Varga, G.; Cassidy, T.; Long, M.; Heyler, K.; Karnati, S.K.R.; Corl, B.; Hovde, C.J.; Yoon, I. Effect of Saccharomyces cerevisiae fermentation product on ruminal fermentation and nutrient utilization in dairy cows. J. Dairy Sci. 2010, 93, 682-692. [CrossRef]

50. Elghandour, M.M.Y.; Khusro, A.; Adegbeye, M.J.; Tan, Z.; Abu Hafsa, S.H.; Greiner, R.; Ugbogu, E.A.; Anele, U.Y.; Salem, A.Z.M. Dynamic role of single-celled fungi in ruminal microbial ecology and activities. J. Appl. Microbiol. 2020, 128, 950-965. [CrossRef]

51. Matthews, C.; Crispie, F.; Lewis, E.; Reid, M.; O'Toole, P.W.; Cotter, P.D. The rumen microbiome: A crucial consideration when optimising milk and meat production and nitrogen utilisation efficiency. Gut Microbes. 2019, 10, 115-132. [CrossRef] [PubMed]

52. Arakaki, L.C.; Stahringer, R.C.; Garrett, J.E.; Dehority, B.A. The effects of feeding monensin and yeast culture, alone or in combination, on the concentration and generic composition of rumen protozoa in steers fed on low-quality pasture supplemented with increasing levels of concentrate. Anim. Feed Sci. Technol. 2000, 84, 121-127. [CrossRef] 